\title{
Aspirin inhibits hepatocellular carcinoma cell proliferation in vitro and in vivo via inducing cell cycle arrest and apoptosis
}

\author{
TINGTING SHI $^{1}$, KOJI FUJITA ${ }^{1}$, JIAN GONG $^{2}$, MAI NAKAHARA ${ }^{1}$, HISAKAZU IWAMA $^{3}$, \\ SHI LIU ${ }^{2}$, HIROHITO YONEYAMA ${ }^{1}$, ASAHIRO MORISHITA ${ }^{1}$, TAKAKO NOMURA ${ }^{1}$, JOJI TANI ${ }^{1}$, \\ KEI TAKUMA ${ }^{1}$, TOMOKO TADOKORO ${ }^{1}$, TAKASHI HIMOTO ${ }^{1}$, KYOKO OURA ${ }^{1}$, \\ KUNIHIKO TSUTSUI $^{1}$, HIDEKI KOBARA ${ }^{1}$ and TSUTOMU MASAKI ${ }^{1}$
}

${ }^{1}$ Department of Gastroenterology and Neurology, Faculty of Medicine, Kagawa University, Kida, Kagawa 761-0793, Japan; ${ }^{2}$ Department of Gastroenterology, The First Affiliated Hospital of Dalian Medical University, Dalian, Liaoning 116011, P.R. China; ${ }^{3}$ Life Science Research Center, Kagawa University, Kida, Kagawa 761-0793, Japan

Received September 23, 2019; Accepted March 10, 2020

DOI: $10.3892 /$ or.2020.7630

\begin{abstract}
Aspirin, a nonsteroidal anti-inflammatory drug (NSAID), is known to inhibit cell proliferation in a variety of cancers. However, the underlying mechanism of this inhibition remains unknown. We investigated the effects of aspirin on hepatocellular carcinoma (HCC) cells using in vitro and in vivo models. Six HCC cell lines and a liver cancer cell line including Huh-7 were used in assays that evaluated cell proliferation, cell cycle, and apoptosis. Flow cytometry, enzyme-linked immunosorbent assay (ELISA), western blot analysis, and phosphorylated receptor tyrosine kinase array were used to evaluate the effects of aspirin on the cells, and microRNAs (miRNAs) were analyzed by a miRNA array chip. The results were validated in vivo using a nude mouse model of Huh-7-xenografted tumors. Our results showed that aspirin exhibited an antiproliferative effect on all cell lines. Moreover, aspirin induced $G_{0} / G_{1}$ cell cycle arrest and modulated the levels of cell cycle-related molecules such as cyclin E, cyclin D1, and cyclin-dependent kinase $2(\mathrm{Cdk} 2)$. In addition, aspirin upregulated the levels of caspase-cleaved cytokeratin 18, increased the proportion of early apoptotic cells, decreased the levels of clusterin and heat shock protein 70 (HSP 70), upregulated the levels of miRNA-137 and inhibited epidermal growth factor receptor (EGFR) activation. In addition, we observed that aspirin suppressed cell
\end{abstract}

Correspondence to: Dr Tsutomu Masaki, Department of Gastroenterology and Neurology, Faculty of Medicine, Kagawa University, 1750-1 Ikenobe, Miki, Kida, Kagawa 761-0793, Japan E-mail: tmasaki@med.kagawa-u.ac.jp

Abbreviations: HCC, hepatocellular carcinoma; NSAID, non-steroidal anti-inflammatory drug; EGFR, epidermal growth factor receptor; HSP 70, heat shock protein 70

Key words: hepatocellular carcinoma, aspirin, microRNA, cell cycle, apoptosis proliferation partially through the miRNA-137/EGFR pathway. Our in vivo results showed that aspirin reduced the growth of xenograft tumors in nude mice. In conclusion, aspirin was able to inhibit the growth of HCC cells by cell cycle arrest, apoptosis, and alteration of miRNA levels in in vitro and in vivo models.

\section{Introduction}

Hepatocellular carcinoma (HCC) accounts for $75-85 \%$ of all primary liver cancer (PLC) cases and is the fourth leading cause of cancer-related deaths worldwide (1). In Asia, liver cirrhosis caused by the hepatitis virus infection contributes to the total number of HCC-associated mortalities. Despite increased awareness and improved clinical diagnosis of HCC, the patient prognosis remains poor (1). A recent American study based on the Surveillance, Epidemiology, and End Results (SEER) 18 Registry Database has shown that the incidence of HCC will continue to rise until 2030 (2). Hence, there is a need for developing effective therapeutic strategies for improved HCC treatment.

Aspirin, one of the classical nonsteroidal anti-inflammatory drugs (NSAIDs), is widely used as an anti-inflammatory and anti-coagulation agent, and for reducing the risk of cardiovascular disorders. Recently, many in vitro and in vivo studies, epidemiological investigations, and randomized clinical trials have generated evidence of the antitumor effects of aspirin in various cancers such as colon (3), breast (4), pancreas (5), and lung (6) cancers. A meta-analysis showed that aspirin is linked to a lower risk of HCC development and a prolonged survival rate of HCC patients (7). According to the latest clinical statistics, regular [ $\geq 2$ standard-dose $(325 \mathrm{mg}$ ) tablets per week] and long-term use of aspirin are associated with a dose-dependent reduction in HCC risk (8). The functional effects of aspirin partly rely on the inhibition of the cyclooxygenase (COX) enzyme; unlike other NSAIDs, the effect of aspirin by this mechanism is irreversible. Furthermore, aspirin is reported to activate key molecular targets in AMPK, mTOR, STAT3 and NF-кB pathways in various carcinomas (4). It is also suggested to suppress cell proliferation by inducing cell cycle arrest and apoptosis (9). 
Regarding HCC cells, aspirin may decrease the levels of reactive oxygen species (ROS) and glucose consumption by downregulating the glucose transporter (10); inducing autophagy via JNK/p-Bcl2/beclin-1, AMPK/mTOR, and GSK-3 signaling pathways (11); inducing apoptosis and mitochondrial dysfunction by increasing oxidative stress (12); and altering the tumor microenvironment due to an effect on platelets $(13,14)$. Therefore, the antitumor effects of aspirin require in-depth investigation in order to completely elucidate its underlying molecular mechanisms.

The aim of the present study was to determine the antitumor effects of aspirin on HCC-derived cell lines and a liver cancer cell line and on an in vivo xenograft tumor model, and to identify the key molecular targets and microRNAs (miRNAs) associated with the functional effects exerted by aspirin.

\section{Materials and methods}

Chemicals. Aspirin was purchased from Wako Pure Chemical Industries, Ltd. (Osaka, Japan). The prepared solution was diluted with the cell culture medium as per cell requirement and used fresh $(\mathrm{pH} 7.2$ to 7.5 , within the range suitable for cell growth).

Cell lines and culture. The HCC cell lines (HLE, HLF, Huh-7, PLC/PRF/5, Hep-3B, Li-7) and a liver cancer cell line (Hep-G2) were obtained from the Japanese Research Resources Bank (Tokyo, Japan). HCC Huh-7 cells were maintained in low glucose Dulbecco's modified Eagle's media (DMEM) (Gibco-Invitrogen; Thermo Fisher Scientific, Inc.) supplemented with $10 \%$ fetal bovine serum (FBS) (533-69545; FUJIFILM Wako) and penicillin/streptomycin (100 mg/l; Invitrogen; Thermo Fisher Scientific, Inc.) Liver cancer Hep-G2 cells and HCC Hep-3B cells were cultured in Modified Eagle's Media (MEM) (Gibco-Invitrogen; Thermo Fisher Scientific, Inc.) supplemented with 10\% FBS and penicillin/streptomycin. HCC HLE and PLC/PRF/5 cells were maintained in DMEM supplemented with $10 \%$ FBS and penicillin/streptomycin. HCC HLF cells were maintained in DMEM supplemented with 5\% FBS and penicillin/streptomycin. HCC Li-7 cells were grown in RPMI-1640 (FUJIFILM Wako) supplemented with $10 \%$ FBS and penicillin/streptomycin. Hepatocytes were grown in endothelial cell medium (ECM) (Upcyte Technologies) with 5\% FBS, penicillin/streptomycin, $1 \%$ supplement A, and $1 \%$ L-glutamine. All cell lines were grown in a humidified incubator at $5 \% \mathrm{CO}_{2}$ and $37^{\circ} \mathrm{C}$.

Cell proliferation assay. The cell proliferation assay was performed using the Cell Counting Kit-8 (Dojindo Laboratories) according to the manufacturer's instructions. HLE, HLF, Huh-7, PLC/PRF/5, Hep-3B, Li-7 and Hep-G2 cells $(5,000$ cells $/ 100 \mu \mathrm{l} /$ well $)$ were seeded in 96 -well plates and allowed to adhere, followed by treatment with different concentrations of aspirin $(0,2.5,5$, or $10 \mathrm{mmol} / \mathrm{l})$ for $48 \mathrm{~h}$ at $37^{\circ} \mathrm{C}$. Subsequently, cells received $100 \mu 1$ of fresh medium containing the CCK- 8 reagent and were incubated for an additional $3 \mathrm{~h}$ at $37^{\circ} \mathrm{C}$. The absorbance was measured at $450 \mathrm{~nm}$ using an automated microplate reader. The experiments were repeated thrice.
Flow cytometric analysis of the cell cycle. To analyze the underlying mechanism of the aspirin-mediated inhibition of tumor cell growth, flow cytometric analyses were performed using the Cycle Phase Determination kit (Cayman Chemical Co.). HCC Huh-7 cells (1.0x10 cells/100-mm diameter dish) were treated with $2.5 \mathrm{mmol} / \mathrm{l}$ aspirin for 24 to $48 \mathrm{~h}$. Cells were scraped and centrifuged to obtain the cell pellet, which was resuspended in phosphate-buffered saline (PBS) $\left(10^{6}\right.$ cells $\left./ \mathrm{ml}\right)$. An equal volume of cell suspension was added to the cycle phase determination fixative and stored at $-20^{\circ} \mathrm{C}$ until further analysis. For cell cycle analysis, the cells were suspended in $100 \mu \mathrm{l}$ of PBS with $10 \mu \mathrm{l}$ RNase A ( $250 \mu \mathrm{g} / \mathrm{ml})$ and $10 \mu \mathrm{l}$ propidium iodide (PI) stain $(100 \mu \mathrm{g} / \mathrm{ml})$, followed by incubation at room temperature in the dark for $30 \mathrm{~min}$. Flow cytometry was performed to compare the proportion of aspirin-treated and control cells in each phase of the cell cycle. Flow cytometry was performed using a Cytomics FC 500 flow cytometer (Beckman Coulter) with an argon laser $(488 \mathrm{~nm})$, and the percentages of cells were analyzed using Kaluza software version v2.1 (Beckman Coulter). The experiments were repeated thrice.

Apoptosis analysis. Aspirin-mediated apoptosis was analyzed using flow cytometry and the Annexin V-FITC Early Apoptosis Detection kit (Cell Signaling Technology, Inc.). Briefly, HCC Huh-7 cells (1.0x $10^{6}$ cells $/ 100-\mathrm{mm}$ dish) were treated with $2.5 \mathrm{mmol} / \mathrm{l}$ aspirin for $48 \mathrm{~h}$ at $37^{\circ} \mathrm{C}$. Cells undergoing apoptosis and necrosis were analyzed by double staining with FITC-conjugated Annexin V and PI as per the manufacturer's protocol. This staining method is based on the binding of Annexin V to apoptotic cells with exposed phosphatidylserines, and the PI-labeling of the damaged membrane in late apoptotic/necrotic cells. Flow cytometry was conducted using a Cytomics FC 500 flow cytometer (Beckman Coulter) with an argon laser (488 $\mathrm{nm}$ ) and data were analyzed using Kaluza software version v2.1 (Beckman Coulter). The experiments were repeated thrice to compare the proportion of apoptotic cells in the aspirin-treated and control groups.

Apoptosis analysis by ELISA. Caspase-cleaved cytokeratin 18 (cCK-18) levels were measured using the M30 Apoptosense ELISA kit (Peviva Ab). Briefly, HCC Huh-7 cells $(5,000$ cells/well) were seeded in 96 -well plates and treated with $2.5 \mathrm{mmol} / 1$ aspirin for $48 \mathrm{~h}$ at $37^{\circ} \mathrm{C}$. Subsequently, the cells were lysed in polyoxyethylene octyl phenyl ether (NP-40) (Wako) and further analyzed according to the manufacturer's instructions.

Western blot analysis. HCC Huh-7 cells were seeded $\left(1.0 \times 10^{6}\right.$ cells $/ 100-\mathrm{mm}$ dish) and treated with $2.5 \mathrm{mmol} / \mathrm{l}$ aspirin for 24 or $48 \mathrm{~h}$. The untreated cells were used as control. The cells were lysed with PRO-PREP complete protease inhibitor mixture (iNtRON Biotechnology). Supernatants were collected and stored at $-80^{\circ} \mathrm{C}$ until further analysis. Protein concentrations were measured using a Nanodrop 2000 spectrofluorometer (Thermo Fisher Scientific, Inc.), and aliquots $(1-10 \mu \mathrm{g})$ were resolved by a $12 \%$ Tris-glycine gradient gel and sodium dodecyl sulfate-polyacrylamide gel electrophoresis (SDS-PAGE). The resolved proteins were transferred to a nitrocellulose membrane and blocked with a blocking buffer. Subsequently, the membranes were incubated with primary antibodies followed by horseradish peroxidase 
(HRP)-conjugated secondary antibodies. The following antibodies were used for developing the blot: primary antibodies against cyclin D1 (SP4) (\#MA5-14512) (dilution 1:500), retinoblastoma protein (Rb) (\#MA1-34070) (dilution 1:1,000), epidermal growth factor receptor (EGFR) (\#PA1-1110) (dilution 1:1,000), and cyclin E (HE-12) (MS-870-P1) (dilution 1:1,000) were obtained from Thermo Fisher Scientific, Inc.; primary antibody against phosphorylated $\mathrm{Rb}(\mathrm{pS} 780)$ (dilution 1:1,000) was obtained from BD Pharmingen; against cyclin-dependent kinase 6 (Cdk6) (sc-177) (dilution 1:500) and Cdk2 (sc-163) (dilution 1:5,000) specific antibodies were obtained from Santa Cruz Biotechnology, Inc.; and anti- $\beta$-actin (A5441) (dilution 1:5,000) was purchased from Sigma-Aldrich (a brand of Merck KGaA). HRP-conjugated anti-mouse (\#7076) (dilution 1:2,000) and anti-rabbit (\#7074) (dilution 1:2,000) IgG secondary antibodies were obtained from Cell Signaling Technology.

Antibody arrays of apoptosis-related and phosphorylated receptor tyrosine kinase ( $p-R T K)$ proteins. HCC Huh-7 cells $\left(1.0 \times 10^{6}\right.$ cells $/ 100-\mathrm{mm}$ dish) were treated with aspirin for $48 \mathrm{~h}$ at $37^{\circ} \mathrm{C}$ and lysed in PRO-PREP complete protease inhibitor mixture (iNtRON Biotechnology). The human Apoptosis Antibody Array kit (R\&D Systems) and Human p-RTK Array kit (R\&D Systems) were used to analyze the apoptosis-related and p-RTK proteins in the aspirin-treated and control cells as per the manufacturer's protocol. Each array was repeated thrice to validate the results.

miRNA assay. HCC Huh-7 cells (1.0x106 cells/100-mm dish) were treated with $2.5 \mathrm{mmol} / \mathrm{l}$ aspirin for $48 \mathrm{~h}$ and total RNA was extracted using the miRNeasy Mini kit (Qiagen) according to the manufacturer's instructions. After confirming the purity and quantity of each RNA using an Agilent 2100 Bioanalyzer (Agilent Technologies) and RNA 6000 Nano kit (Agilent Technologies) respectively, the samples were labeled using a miRCURY Hy3 Power Labeling kit (Exiqon A/S) and hybridized to a human miRNA Oligo Chip (v.21; Toray Industries, Inc.). Scanning was conducted using the 3D-Gene Scanner 3000 (Toray Industries). The 3D-Gene extraction software version 1.2 (Toray Industries) was used to calculate the raw signal intensity of the images. The raw data were analyzed using GeneSpring GX 10.0 software (Agilent Technologies) to assess the differences in miRNA expression between the aspirin-treated and control samples. Global normalization was performed on raw data obtained above the background level. Differentially expressed miRNAs were determined using the Welch's t-test. The false discovery rate (FDR) was computed using the Benjamini-Hochberg method. Hierarchical clustering was performed using the farthest neighbor method with the absolute uncentered Pearson's correlation coefficient as a metric. The heatmap was produced with the relative expression intensity of each miRNA, in which the base- 2 logarithm of intensity was median-centered for each row.

Reverse transcription-quantitative polymerase chain reaction (RT-qPCR) analysis of miRNAs. We compared the miRNA expression levels obtained in the miRNA arrays with real-time qPCR measurements to validate the data for miR-137 and miR-7-5p, which were significantly modulated according to the microarray analysis. Total RNA was extracted and a diluted sample $(2.0 \mathrm{ng} / \mu \mathrm{l})$ was used in TaqMan microRNA assays (Applied Biosystems) to determine the expression levels of miRNAs; U6 small nuclear RNA (RNU6B) was used as the internal control. miRNAs were reverse transcribed using the TaqMan microRNA Reverse Transcription kit (Applied Biosystems). The reverse transcription reaction mixture was prepared in $15-\mu 1$ reaction volumes with the following constituents: $5 \mu \mathrm{l}$ of RNA, $3 \mu \mathrm{l}$ of $5 \mathrm{X}$ RT primer and $7 \mu \mathrm{l}$ of reverse transcription Master Mix. PCRs were performed in the MicroAmp Fast Optical 96-Well Reaction Plate (Applied Biosystems). For real-time qPCR, reaction mixtures were prepared in $20-\mu 1$ volumes with $2 \mu \mathrm{l}$ of cDNA, $1 \mu \mathrm{l}$ of $20 \mathrm{X}$ qPCR assay, $7 \mu \mathrm{l}$ of nuclease-free water and $10 \mu \mathrm{l}$ of TaqMan Fast Advanced Master Mix (Applied Biosystems). The PCRs were carried out using the ViiA7 real-time PCR system (Applied Biosystems) with the following reaction steps: Hold at $50^{\circ} \mathrm{C}$ for $2 \mathrm{~min}$, denaturation at $95^{\circ} \mathrm{C}$ for $20 \mathrm{sec}$ followed by 40 cycles of $1 \mathrm{sec}$ at $95^{\circ} \mathrm{C}$ and $20 \mathrm{sec}$ at $60^{\circ} \mathrm{C}$. The relative expression levels of miR-137 and miR-7-5p were calculated using the comparative $\mathrm{Ct}$ method according to the following formula: $2^{-\Delta \Delta \mathrm{Cq}}(\Delta \mathrm{Cq}=\mathrm{miRCq}-\mathrm{U} 6 \mathrm{Cq})(15)$.

Cell transfection. HCC Huh-7 cells were transfected with the miR-137 mimic (3'-GAUGCGCAUAAGAAUUCGUUA UU-5') (50 nM) or scrambled miRNA (3'-TTAAGAGGC CUGUGCAAGCCUCUU-5') as a control (Life Technologies; Thermo Fisher Scientific, Inc.) using Lipofectamine RNAiMAX Reagent (Invitrogen; Thermo Fisher Scientific, Inc.). Briefly, $5 \times 10^{5}$ cells were seeded in 6 -well plates with antibiotic-free medium 1 day before transfection to reach a confluence of $90 \%$ at the time of transfection. The transfection complex was prepared according to the manufacturer's instructions and added to the cells, and the plates were incubated in a humidified atmosphere with $5 \% \mathrm{CO}_{2}$ at $37^{\circ} \mathrm{C}$. The medium was replaced $6 \mathrm{~h}$ post-transfection. Cell samples were collected 0 or $72 \mathrm{~h}$ after transfection for further analysis.

Colony forming assay. Cells prepared for assay were trypsinized for $5 \mathrm{~min}$ and resuspended; $500 \mu \mathrm{l}$ of cells $(500 / \mathrm{ml})$ were seeded in 6-well plates and to each well we added $1.5 \mathrm{ml}$ DMEM (containing 10\% FBS). The plates were incubated at $37^{\circ} \mathrm{C}$ in $5 \% \mathrm{CO}_{2}$, and the medium was changed every 3 days until conspicuous colonies were observed. Finally, the colonies were stained with $0.1 \%$ crystal violet for $5 \mathrm{~min}$ at room temperature and counted using a microscope.

Xenograft model analysis. The animal study was approved by and conducted in accordance with guidelines set by the Committee on Experimental Animals of the Kagawa University. Female athymic mice (BALB/c-nu/nu; 6 weeks old; 19-21 g) were purchased from Japan SLC (Shizuoka, Japan). The mice were maintained under specified pathogen-free conditions using a laminar airflow rack and had continuous free access to sterilized ( $\gamma$-irradiated) food (CL-2; Clea Japan, Tokyo) and autoclaved water. Mice were subcutaneously inoculated with HCC Huh7 cells $\left(1 \times 10^{6}\right.$ cells/mice) in the right flank region. Once the xenografts were identifiable as masses with a maximal diameter $>3 \mathrm{~mm}$, the animals were randomly assigned to 2 groups of 7 animals each. These groups were 

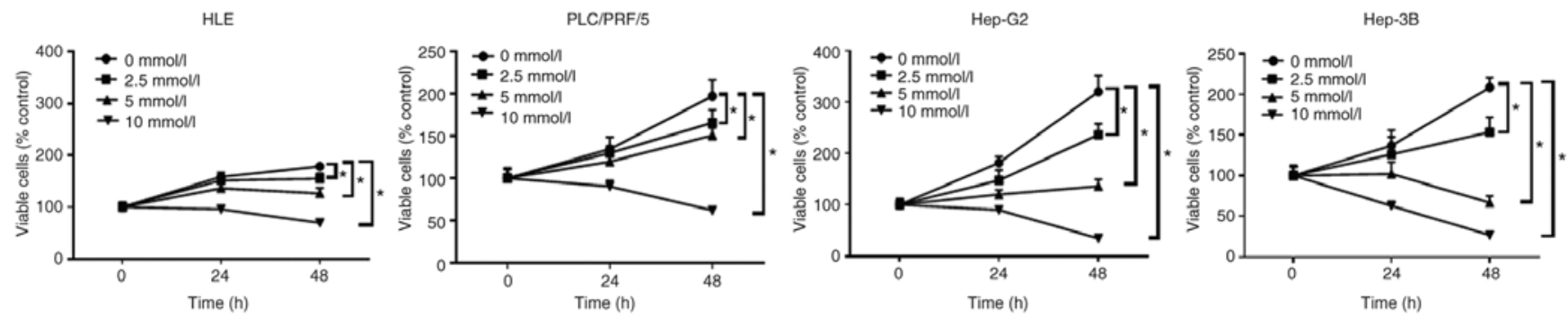

HLF
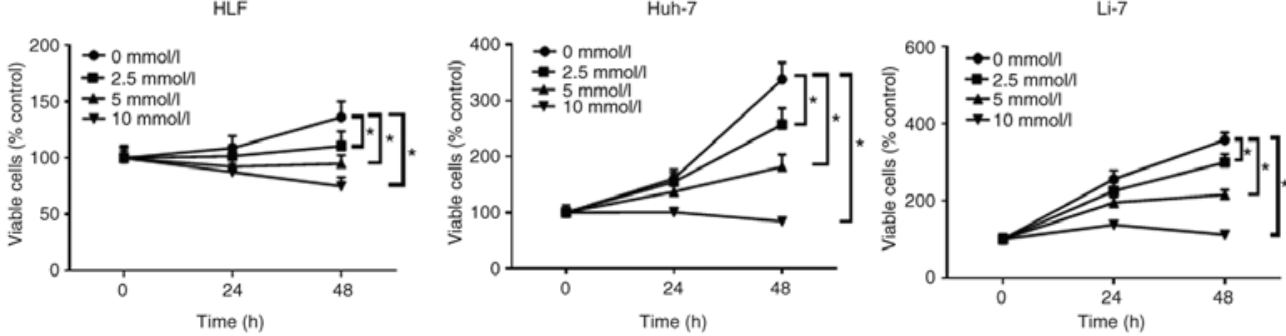

Figure 1. Aspirin inhibits the proliferation of human $\mathrm{HCC}$ cells and a hepatoblastoma cell line. All cell lines were treated with $0,2.5,5$, or $10 \mathrm{mmol} / 1$ aspirin for 24 or $48 \mathrm{~h}$. The data points represent the mean cell number from three independent cultures, and the error bars represent standard deviations (SDs). The antiproliferative effect of the aspirin treatment was significantly higher in the HCC and liver cancer cells at $48 \mathrm{~h}$ when compared to the untreated control cells ( $0 \mathrm{mmol} / \mathrm{l})$ by two-way ANOVA ( $\mathrm{P}<0.01$, vs. the control). HCC, hepatocellular carcinoma.

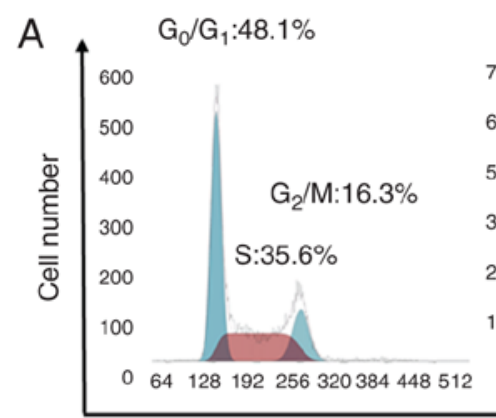

$24 \mathrm{~h}(-)$

$24 \mathrm{~h}$

B

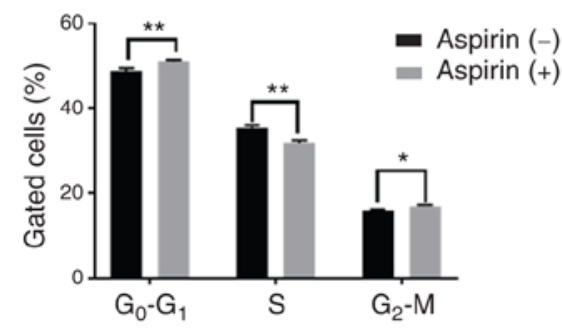

$\mathrm{G}_{0} / \mathrm{G}_{1}: 51.4 \%$

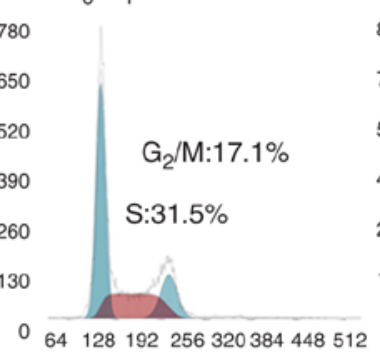

$\mathrm{G}_{0} / \mathrm{G}_{1}: 52.9 \%$

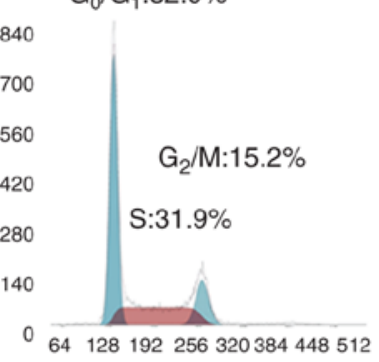

$\mathrm{G}_{0} / \mathrm{G}_{1}: 58.3 \%$

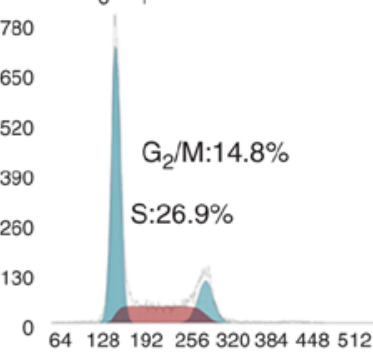

$48 \mathrm{~h}(+)$

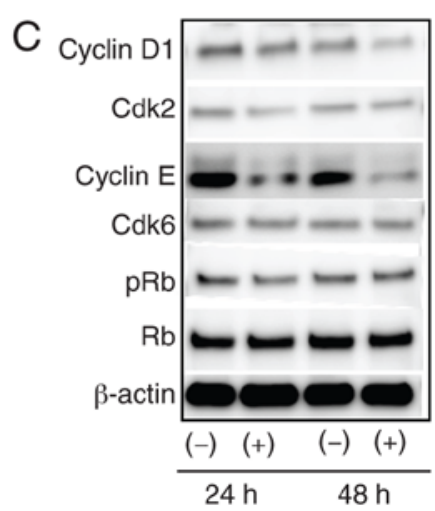

Figure 2. Antiproliferative effects of aspirin in HCC cells by cell cycle arrest. (A) Huh-7 cells treated without or with 2.5 mmol/1 aspirin were analyzed by flow cytometry to estimate the number of cells in each phase of the cell cycle. (B) The histogram represents the percentage of cells in each cell cycle phase. Aspirin blocked the cell cycle at the $\mathrm{G}_{0} / \mathrm{G}_{1}$ phase. ( ${ }^{*} \mathrm{P}<0.05,{ }^{* *} \mathrm{P}<0.01$, vs. the control). (C) Expression of cyclin D1, cyclin-dependent kinase (Cdk6), cyclin E, Cdk2, retinoblastoma protein $(\mathrm{Rb})$ and phosphorylated $\mathrm{Rb}(\mathrm{pRb})$ in Huh-7 cells 24 and $48 \mathrm{~h}$ after aspirin treatment. HCC, hepatocellular carcinoma.

treated with $60 \mathrm{mg} / \mathrm{kg}$ of aspirin or vehicle (PBS, $10 \%$ ethanol) by intraperitoneal injection every day. The tumor growth was monitored daily and the tumor volume $(\mathrm{V})\left(\mathrm{mm}^{3}\right)$ was calculated as $\mathrm{V}=$ tumor length $(\mathrm{mm}) \mathrm{x}$ tumor width $(\mathrm{mm})^{2} / 2$. All animals were sacrificed on day 12 after the beginning of the treatment. Notably, all animals remained alive during this period.
Statistical analysis. GraphPad Prism software version 6.0 (GraphPad Software, USA) was used for all the analyses. A Student's t-test was used to determine statistical significance between different groups. Two-way analysis of variance (ANOVA) or mixed ANOVA was performed to test the comparisons and corrected by the Tukey's post hoc test. Results with P-value $<0.05$ were considered statistically significant. 
A

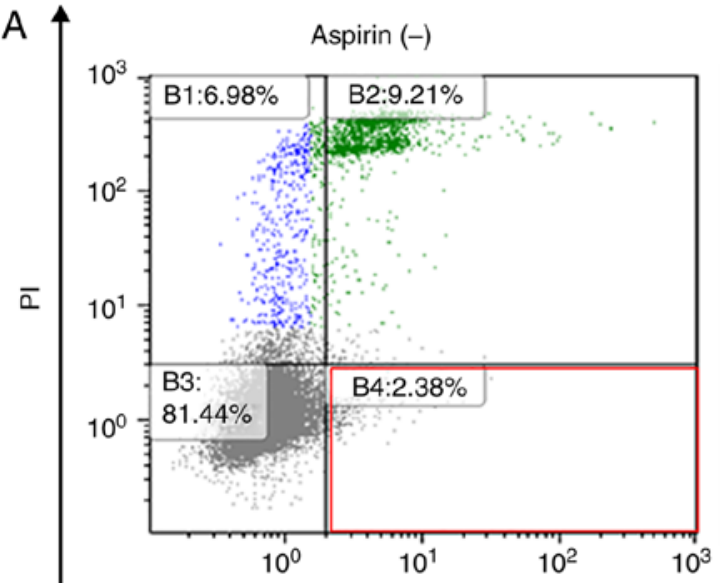

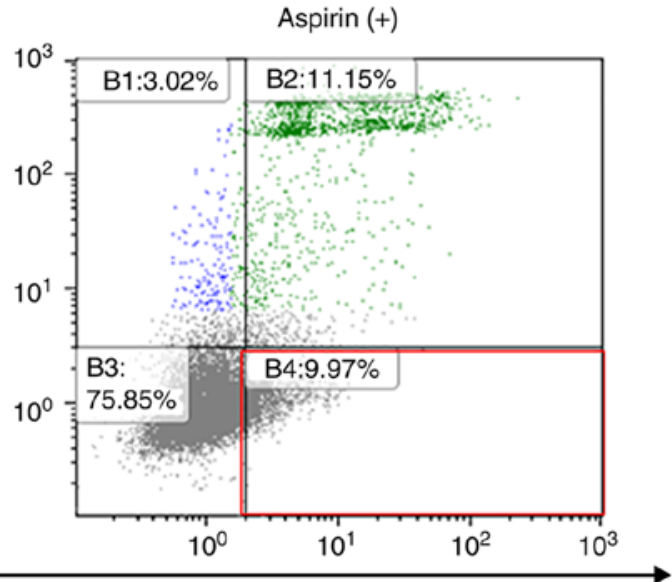

Annexin V-FITC

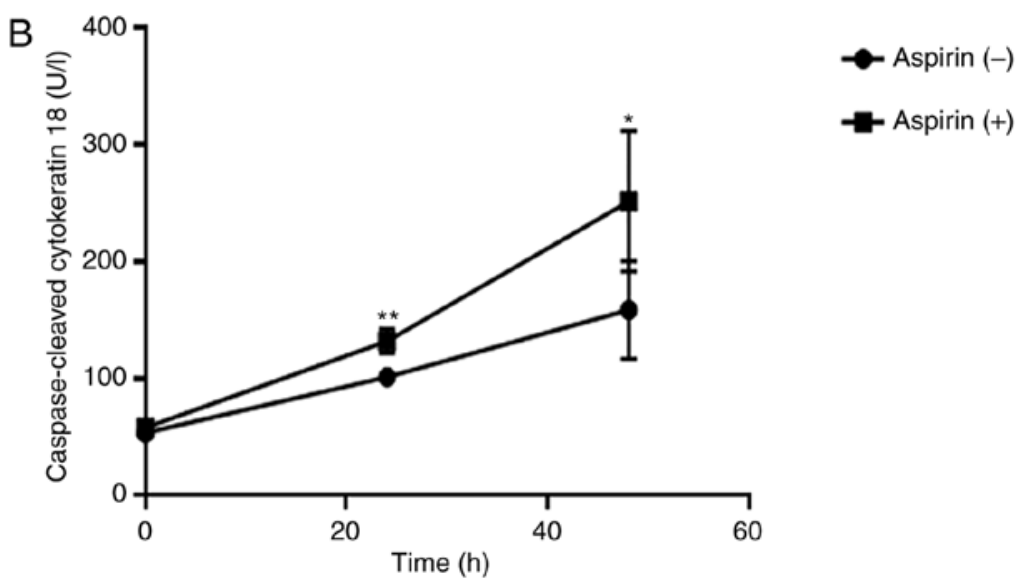

Figure 3. Aspirin induces apoptosis in HCC Huh-7 cells. (A) The early apoptotic changes evoked by $2.5 \mathrm{mmol} / 1$ aspirin at $48 \mathrm{~h}$ were assessed by flow cytometry. Aspirin treatment changed the proportion of early apoptotic Huh-7 cells in the population. (B) The expression of caspase-cleaved cytokeratin 18 (cCK-18) was determined using ELISA after 24 or $48 \mathrm{~h}$ of $2.5 \mathrm{mmol} / 1$ aspirin treatment. (" $\mathrm{P}<0.05,{ }^{* *} \mathrm{P}<0.01$, vs. the control). HCC, hepatocellular carcinoma.

\section{Results}

Aspirin inhibits the proliferation of 6 human HCC and a liver cancer cell line. The anti-proliferative effects of aspirin on human liver cancer cells were determined using the following cell lines: Huh-7, Hep-G2, Hep-3B, Li-7, HLE, HLF and PLC/PRF/5. Each cell line was treated with 2.5, 5, or $10 \mathrm{mmol} / \mathrm{l}$ aspirin for $48 \mathrm{~h}$, followed by the estimation of the anti-proliferative activity of aspirin using a cell proliferation assay. Untreated cells were used as control. Our results revealed that aspirin significantly inhibited cell proliferation in all liver cancer cell lines in a dose- and time-dependent manner (Fig. 1).

Aspirin induces cell cycle arrest in the $G_{0} / G_{1}$ phase and regulates cell cycle-related proteins in HCC Huh-7 cells. Based on the anti-proliferation assay, HCC Huh-7 cells are sensitive to aspirin. In addition, considering the xenograft model, Huh-7 cells can be easily transplanted and present black xenograft tumors, providing clear observation and measurement. To study whether aspirin affects the cell cycle in Huh-7 cells, flow cytometry was performed to examine cell cycle progression and western blotting was carried out to evaluate the expression of cell cycle-related proteins. Cells were treated with
$2.5 \mathrm{mmol} / \mathrm{l}$ aspirin for 24 or $48 \mathrm{~h}$, and untreated cells were used as control. We observed that following aspirin treatment for 24 and $48 \mathrm{~h}$, the cell population in the $G_{0} / G_{1}$ phase was significantly increased, while cells in the $S$ phase were significantly decreased (Fig. 2A and B). Western blot results showed that aspirin treatment significantly modulated cyclin $\mathrm{E}$, a key protein implicated in the transition from $G_{0} / G_{1}$ phase to the $\mathrm{S}$ phase. Additionally, $\mathrm{Cdk} 2$, the catalytic subunit of cyclin E, was decreased after 24 and $48 \mathrm{~h}$ of aspirin treatment. The expression of cyclin D1 decreased slightly after $48 \mathrm{~h}$ of aspirin treatment, whereas the levels of phosphorylated $\mathrm{Rb}$ decreased progressively after $24 \mathrm{~h}$, suggesting that the treated cells were in $\mathrm{G}_{1}$ phase arrest (Fig. 2C).

Aspirin partially induces cell apoptosis in the Huh-7 cells. Flow cytometry was used to detect apoptotic cells after aspirin treatment. The different quadrants represent living cells (lower left square), early apoptotic cells (lower right square), and late apoptotic cells (upper right square). After $48 \mathrm{~h}$ of treatment, a higher percentage of cells (9.97\%) were early apoptotic in the $2.5 \mathrm{mmol} / \mathrm{l}$ aspirin-treated group in comparison to the control group (2.38\%, Fig. 3A). In related results, aspirin significantly increased the levels of cCK-18 after 24 and $48 \mathrm{~h}$ of treatment (Fig. 3B). 
Table I. Statistical results and chromosomal locations of miRNAs that exhibited a fold change $(\mathrm{FC})>1.5, \mathrm{FC}<0.67$, or $\mathrm{P}<0.05$ in HCC Huh-7 cells treated with aspirin when compared with untreated cells.

\begin{tabular}{lllc}
\hline miRNA & Fold change (treated/untreated) & P-value & Chromosomal location \\
\hline $\begin{array}{l}\text { Upregulated } \\
\text { hsa-miR-4716-3p }\end{array}$ & 2.597567946 & & \\
hsa-miR-137 & 2.049649799 & 0.0460088 & 15 \\
hsa-miR-6790-3p & 1.989701339 & 0.00398366 & $1 \mathrm{p} 21.3$ \\
hsa-miR-181c-5p & 1.700223375 & 0.0321397 & 19 \\
hsa-miR-1225-5p & 1.607423491 & 0.0150924 & 19 \\
hsa-miR-6774-5p & 1.589034149 & 0.00100997 & 16 \\
hsa-miR-4538 & 1.504758828 & 0.00181634 & 16 \\
Downregulated & & 0.0281657 & $14 \mathrm{q} 32.33$ \\
hsa-miR-455-5p & 0.657530227 & & \\
hsa-miR-7-5p & 0.641358785 & 0.00349551 & 9 \\
hsa-miR-487a-3p & 0.620582971 & 0.000504317 & 9 \\
hsa-miR-4701-3p & 0.536963485 & 0.0388511 & 14 \\
hsa-miR-891a-5p & 0.520306733 & 0.040636 & 12 \\
hsa-miR-5580-5p & 0.459580271 & 0.0329557 & Xq27.3 \\
\hline
\end{tabular}

HCC, hepatocellular carcinoma.

\begin{tabular}{|c|c|c|c|c|c|c|c|c|c|c|c|}
\hline $\begin{array}{l}\text { Reference } \\
\text { spots }\end{array}$ & & & & & & & & & & & $\begin{array}{c}\text { Reference } \\
\text { spots }\end{array}$ \\
\hline Bad & Bax & $\mathrm{Bcl}-2$ & $B c 1-x$ & $\begin{array}{c}\text { Pro- } \\
\text { caspase-3 }\end{array}$ & $\begin{array}{c}\text { Cleaved } \\
\text { caspase-3 }\end{array}$ & Catalase & CIAP-1 & CIAP-2 & Claspin & Clusterin & $\begin{array}{l}\text { Cytochrome } \\
\text { C }\end{array}$ \\
\hline $\begin{array}{c}\text { TRAIL } \\
\text { R1/DR4 }\end{array}$ & $\begin{array}{l}\text { TRAIL } \\
\text { R2/DR5 }\end{array}$ & FADD & $\begin{array}{c}\text { Fas/TNFRSF } \\
6 / \text { CD95 }\end{array}$ & $\mathrm{HIF}=1 \alpha$ & $\begin{array}{c}\text { HO- } \\
\text { 1/HMOX1/HS } \\
\text { P32 }\end{array}$ & HO-2/HMOX2 & HSP27 & HSP60 & HSP70 & HTRA2/Omi & Livin \\
\hline PON2 & $\begin{array}{c}\mathrm{p} 21 / \mathrm{CIP} 1 / \mathrm{CD} \\
\mathrm{KN} 1 \mathrm{~A}\end{array}$ & p27/Kip1 & $\begin{array}{l}\text { Phospho- } \\
\text { p53 (S15) }\end{array}$ & $\begin{array}{l}\text { Phospho- } \\
\text { p53 (S46) }\end{array}$ & $\begin{array}{l}\text { Phospho- } \\
\text { p53 (S392) }\end{array}$ & $\begin{array}{l}\text { Phospho- } \\
\text { Rad17 (S635) }\end{array}$ & SMAC/Diablo & Survivin & $\begin{array}{c}\text { TNF } \\
\text { RI/TNFRSF1 } \\
A\end{array}$ & XIAP & PBS \\
\hline $\begin{array}{l}\text { Reference } \\
\text { spots }\end{array}$ & & & & & & & & & & & \\
\hline
\end{tabular}

B
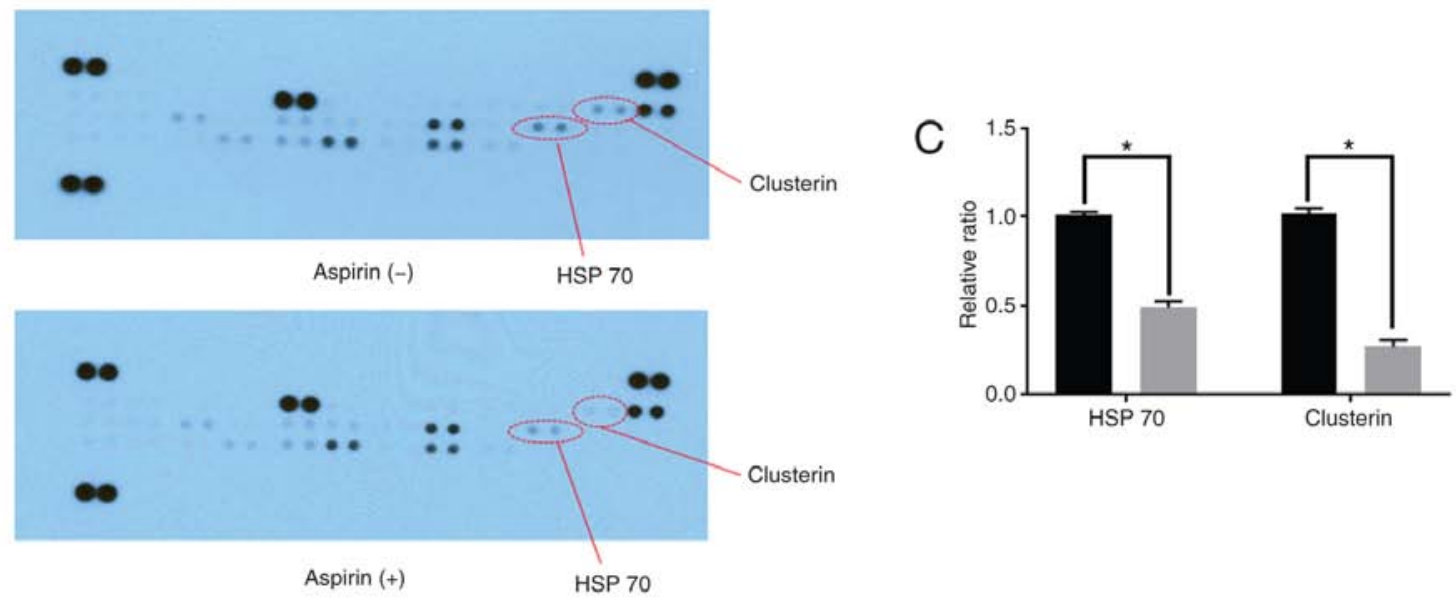

- Aspirin (-) Aspirin (+)

Figure 4. Effects of aspirin on apoptosis in HCC Huh-7 cells. (A) The above template indicates the locations of proteins on a human apoptosis array. (B) Representative expression of various apoptosis-related proteins in Huh-7 cells incubated with or without $2.5 \mathrm{mmol} / \mathrm{l}$ aspirin for $48 \mathrm{~h}$. (C) Densitometry analysis indicated the ratio of clusterin and HSP 70 spots in aspirin-treated compared with untreated cells ( $\mathrm{P}<0.01$, vs. the control). HCC, hepatocellular carcinoma.

Using an apoptosis array system, we identified apoptosis-associated proteins involved in the antitumor effects of aspirin. We observed that aspirin decreased the levels of stress proteins, HSP 70, and clusterin in the HCC Huh-7 cells (Fig. 4A and B). Densitometric analyses showed that the intensities of HSP 70 and clusterin spots from aspirin-treated Huh-7 cells were 48 and $63 \%$ weaker than those from the control cells, respectively (Fig. 4C).

Aspirin affects miRNA expression in Huh-7 cells. A customized microarray platform was used to analyze the expression of 2,555 miRNAs in the aspirin-treated or control Huh-7 cells. Treatment 


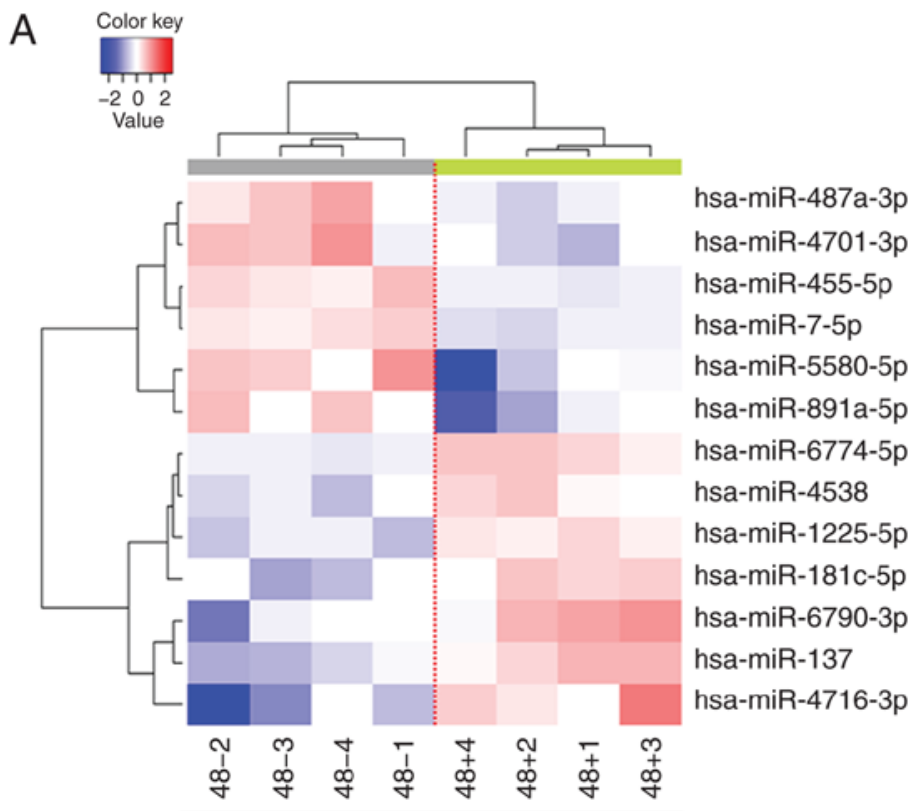

Aspirin (-) (+)

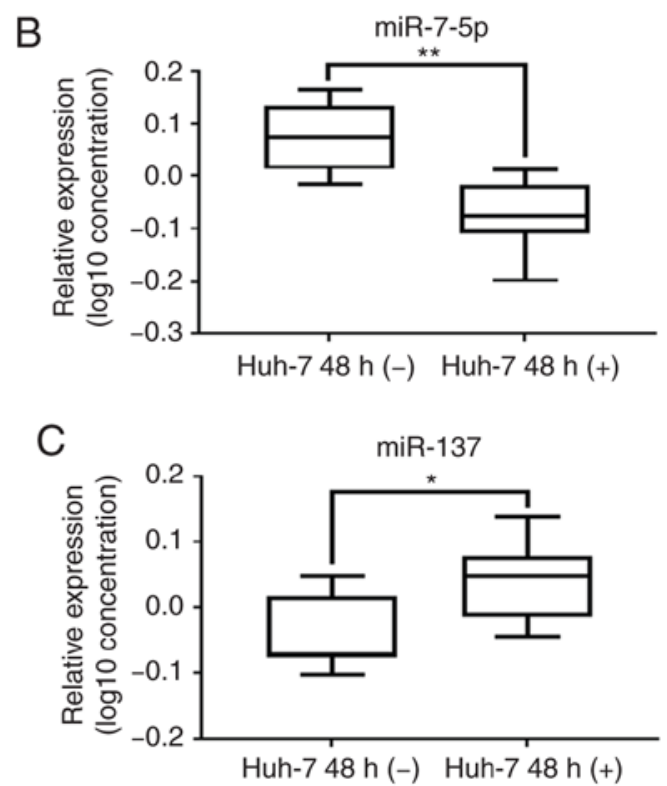

Figure 5. Aspirin affects miRNA expression in HCC Huh-7 cells. (A) Hierarchical clustering of expression profiles of numerous differentially expressed miRNAs from HCC Huh-7 cells cultured with or without aspirin. (B) Real-time qPCR relative quantification (RQ) of miRNA following aspirin treatment. miR-7-5p expression was significantly downregulated $\left({ }^{* *} \mathrm{P}<0.01\right.$, vs. the control). (C) miR-137 expression after aspirin treatment was significantly upregulated $\left({ }^{*} \mathrm{P}<0.05\right.$, vs. the control). The $\log _{10} 2^{-\Delta \Delta \mathrm{Cq}}$ value for miRNA was used to create the figure and the lines represent averages with interquartile ranges. HCC, hepatocellular carcinoma.

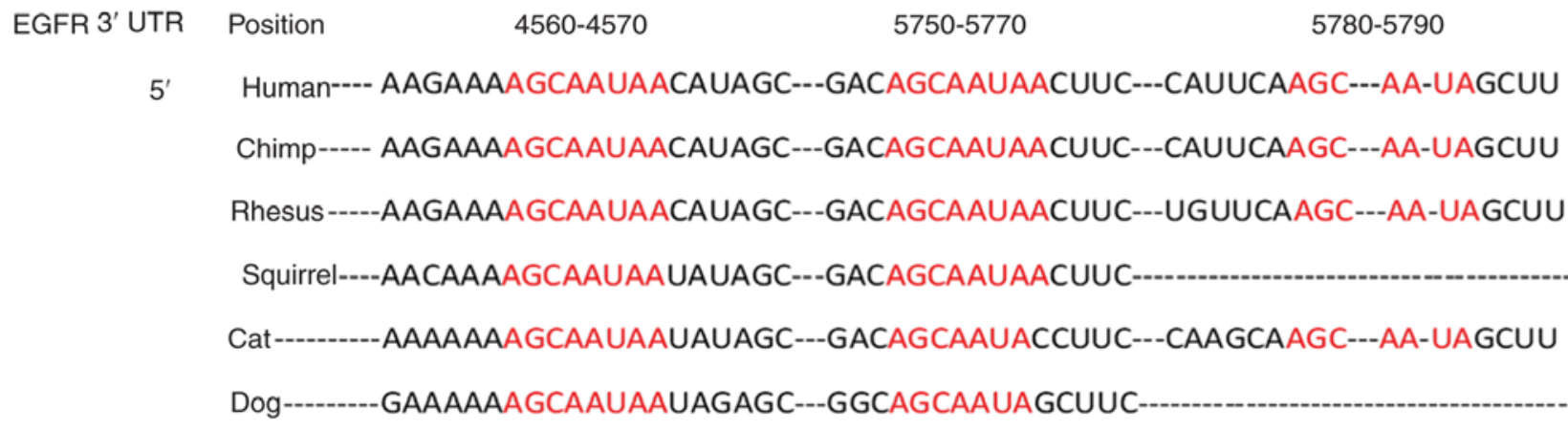

Elephant-GACAGCAAUAACUUC---CAUUCAAGC---AA-UACCUU

\begin{tabular}{|c|c|c|}
\hline & & Seed sequence \\
\hline EGFR 3' UTR human & $5^{\prime}$ & UGUACAUGUAAGAAAAGCAAUAA... \\
\hline Mature human miR-137 & $3^{\prime}$ & 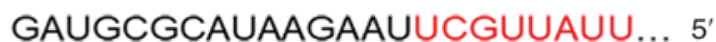 \\
\hline
\end{tabular}

Figure 6. The seed sequence of human miR-137 is complementary to the 3'UTR of EGFR. EGFR, epidermal growth factor receptor; 3' UTR, 3'untranslated region.

with $2.5 \mathrm{mmol} / \mathrm{l}$ aspirin for $48 \mathrm{~h}$ induced the upregulated expression of 7 miRNAs, among which the expression of miR-137 was found to be significantly upregulated; meanwhile, the expression of 6 miRNAs was suppressed (Table I), and the expression of miR-7-5p was found to be significantly downregulated.

Unsupervised hierarchical clustering analysis was conducted by calculating Pearson's centered correlation coefficient, and the results indicated that aspirin-treated Huh-7 cells clustered together (Fig. 5A). The results of the qPCR assay confirmed that miR-7-5p levels were significantly decreased (Fig. 5B) and miR-137 levels were significantly upregulated (Fig. 5C) in the aspirin-treated cells compared to the untreated cells.

miRNA-137 inhibits the proliferation of Huh-7 cells and decreases the expression levels of EGFR. The prediction of the miRNA target gene (www.targetscan.org) showed that the mature human miR-137 target was consistent with the partial sequence of EGFR (Fig. 6). Relative quantification of miR-137 

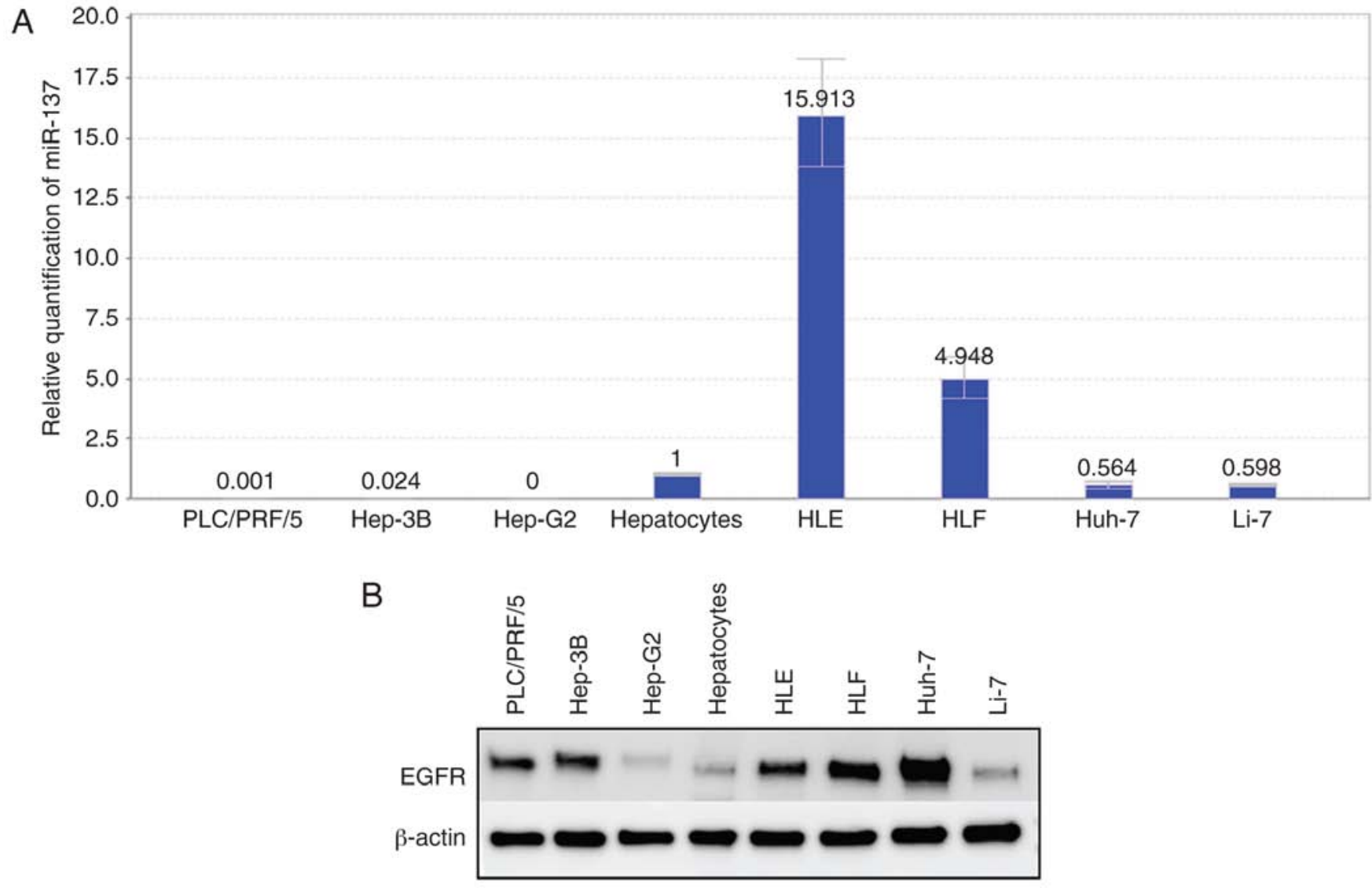

Figure 7. Expression levels of miR-137 and EGFR in human HCC and liver cancer cells and hepatocytes. (A) Relative quantification of miR-137 in normal hepatocytes, human HCC and liver cancer cells. (B) Expression levels of EGFR in normal hepatocytes and human HCC and liver cancer cells. EGFR, epidermal growth factor receptor; HCC, hepatocellular carcinoma.

was detected in all cell lines. In the differentiated cell lines, the miR-137 levels were downregulated, and in the undifferentiated cell lines (HLE, HLF), miR-137 levels were upregulated (Fig. 7A). Fig. 1 shows that cell lines with low expression of miR-137 were more sensitive to aspirin treatment. In addition, the expression levels of EGFR in hepatoma cell lines were almost as upregulated as those in normal hepatocytes (Fig. 7B). After transfection of miR-137 mimics, miR-137 expression was significantly increased in the Huh-7 cells (Fig. 8A). Our results indicated that the overexpression of miR-137 inhibited Huh-7 cell proliferation (Fig. 8B). After transfection with miR-137, the levels of EGFR were downregulated (Fig. 8C), and the colony formation assay indicated that overexpression of miR-137 decreased the cell proliferation ability of Huh-7 cells (Fig. 8D). Meanwhile, we used a p-RTK array system to identify the levels of p-EGFR after aspirin treatment, also showing that aspirin inhibited the expression of p-EGFR in the treated Huh-7 cells (Fig. 8E). Aspirin therefore upregulated miR-137 levels, inhibiting EGFR expression and decreasing cell proliferation ability (Fig. 8F).

Aspirin inhibits tumor proliferation in vivo. Based on the results obtained from in vitro studies, nude mice were injected subcutaneously with Huh-7 cells followed by intraperitoneal injection of aspirin. Our results showed that tumor growth was significantly inhibited in the mice treated with aspirin compared to the untreated mice $(\mathrm{P}<0.05$; Fig. 9A).
Histopathological sections of xenografted tumors revealed an invariable encapsulation by connective tissue and no significant histopathological differences between the aspirin-treated and control mice, except for the size of the tumor (Fig. 9B). Additionally, the body weight of aspirin-treated mice was slightly lower than that of the untreated mice (data not shown). All mice survived for the entire observation period.

\section{Discussion}

Recent studies have reported that aspirin may have a role in the prevention and improvement of HCC outcomes $(7,8)$, but conflicting results from sparse studies warrant further investigation of the anti-proliferative effects of aspirin on hepatocellular carcinoma (HCC) cells. The present study showed that aspirin was indeed capable of inhibiting the proliferation of HCC cells.

HCC is associated with high morbidity and a poor patient survival rate, thus effective therapeutic strategies are urgently needed for improving the disease outcome (1). Aspirin, a vastly used drug, has been evaluated for its anti-proliferative activities, and evidence from multiple studies has indicated that it may function effectively in the prevention of various tumors, including HCC $(10,11)$. In the present study, we demonstrated that aspirin exerted antitumor effects on HCC by inducing cell cycle arrest and apoptosis and suppressing cell proliferation partially through the microRNA-137/epidermal growth factor 

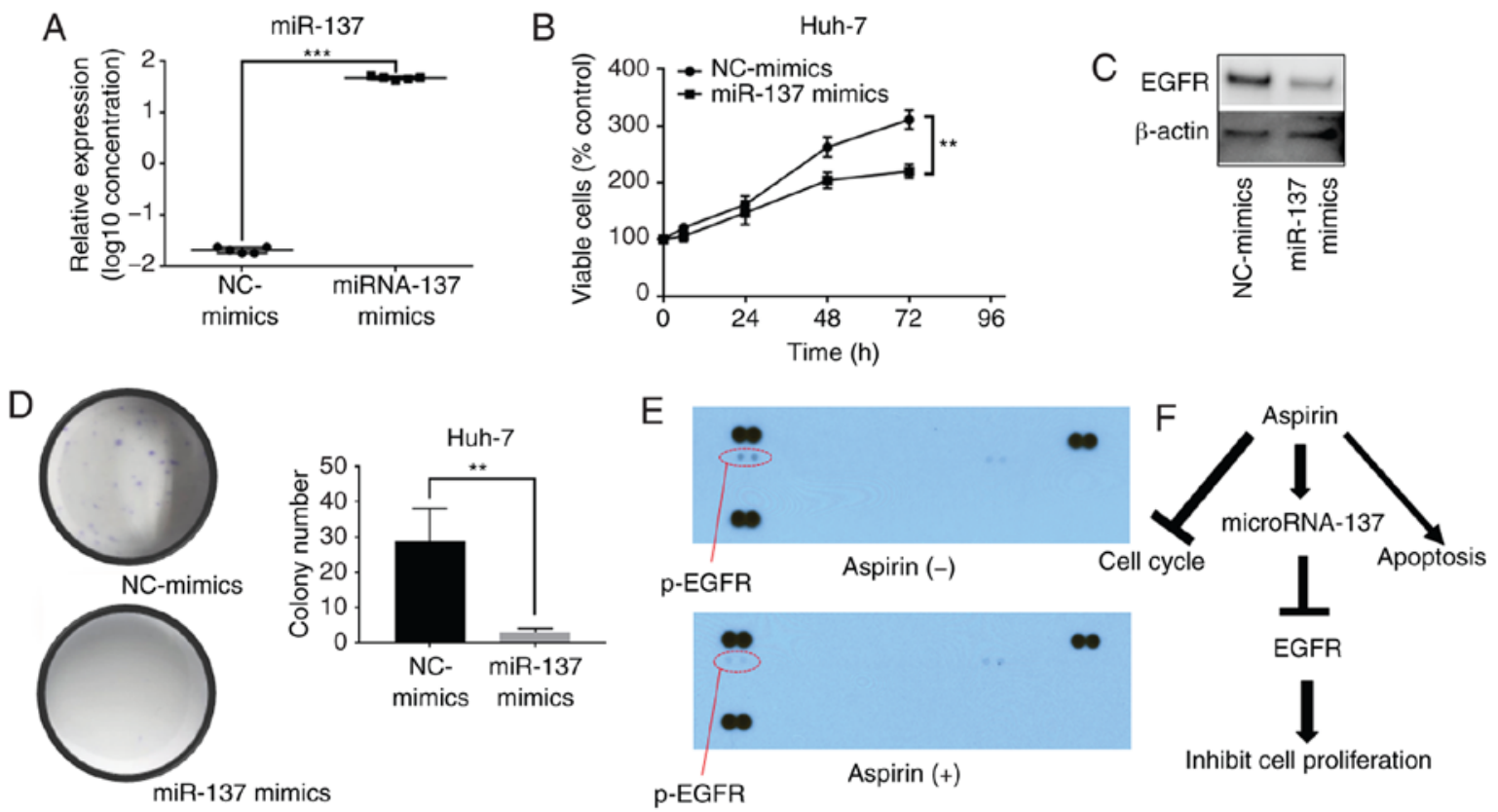

Figure 8. Effects of miR-137 on HCC Huh-7 cells. (A) Real-time qPCR relative quantification of miRNA-137 following miRNA-137 mimic or negative control (NC) mimic transfection. (B) miR-137 overexpression inhibited cell proliferation in Huh-7 cells. (C) The expression levels of EGFR after NC-mimic or miR-137 mimic transfection. (D) Colony formation assay after transfection: miR-137 overexpression inhibited colony formation. (E) Representative expression of various phosphorylated tyrosine kinase receptors in Huh-7 cells incubated without or with $2.5 \mathrm{mmol} / 1$ aspirin for $48 \mathrm{~h}$. (F) Aspirin upregulates the levels of miR-137, inhibiting EGFR expression and thus decreasing cell proliferation ability. $\left({ }^{* *} \mathrm{P}<0.01,{ }^{* * * *} \mathrm{P}<0.001\right.$, vs. the control). EGFR, epidermal growth factor receptor; HCC, hepatocellular carcinoma.
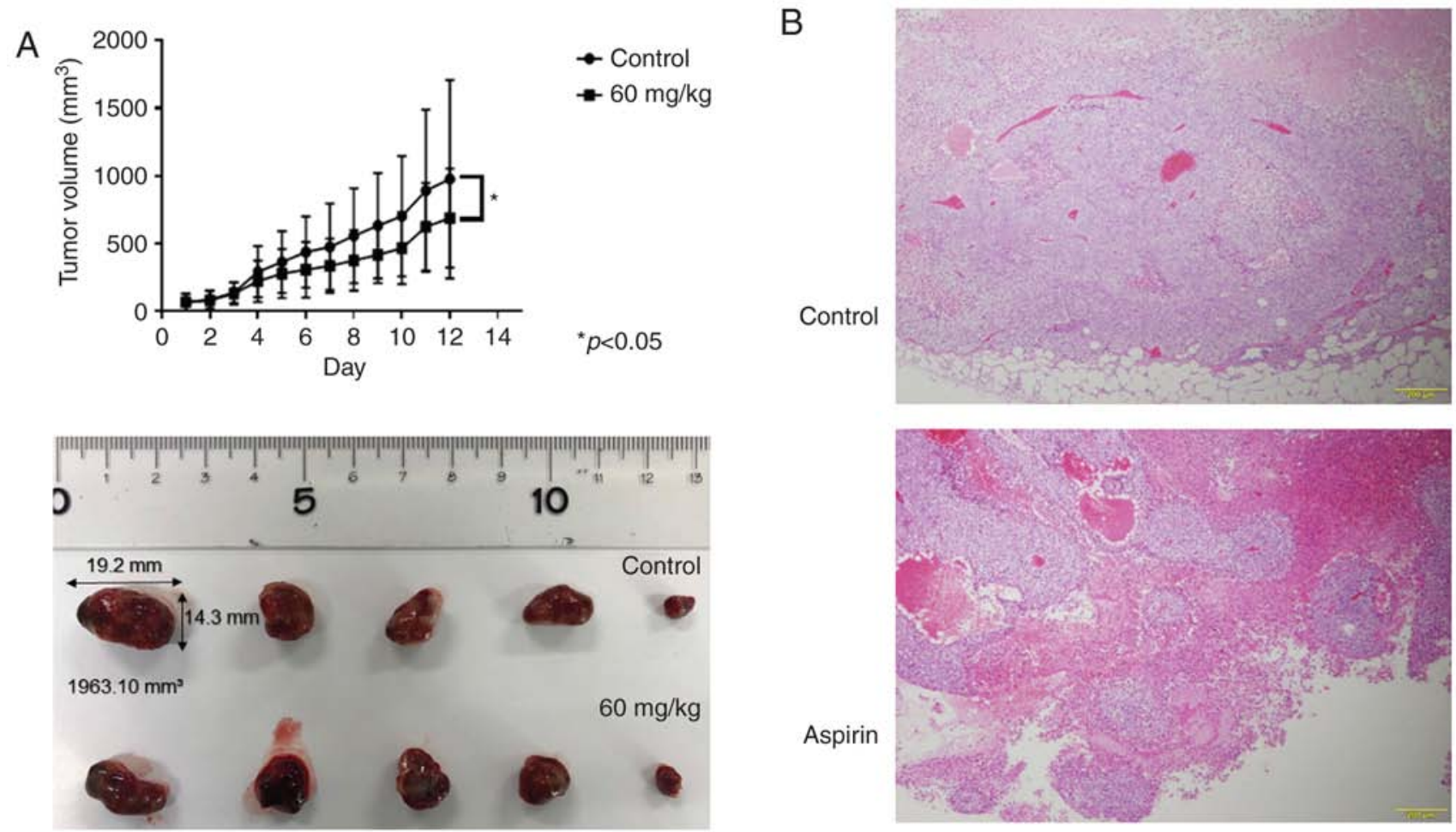

Figure 9. Aspirin inhibits the growth of HCC Huh-7 cell xenografts in nude mice. (A) The tumor volumes were significantly smaller in aspirin-treated mice compared with those in the vehicle-treated mice. Each point represents the mean \pm standard deviation of 7 animals ("P $<0.05$ by mixed ANOVA). (B) Hematoxylin and eosin (H\&E)-stained images of the xenografted tumor tissues in the aspirin-treated and control groups. HCC, hepatocellular carcinoma.

receptor (EGFR) pathway. Aspirin is used for its antiplatelet, analgesic, and anti-inflammatory effects over a wide dosage ranging from 75 to $1,200 \mathrm{mg}(16)$. Recent analyses indicate a significant inverse association between aspirin dose and the risk of liver cancer (17). Some studies have shown that similarly to aspirin, salicylic acid exhibits anti-proliferative and antitumor 
activity in vitro and in vivo $(18,19)$, although in this study we specifically researched only the aspirin concentration.

In the present study, aspirin treatment induced cell cycle arrest at the $G_{0} / G_{1}$ phases and significantly decreased the levels of cell cycle-related proteins such as cyclin E, cyclin D1, and cyclin-dependent kinase $2(\mathrm{Cdk} 2)$ in the HCC Huh-7 cells. Cyclin, cyclin-dependent kinase and cyclin-dependent kinase inhibitor work together in regulating the cell cycle phase. Cyclin D1 is expressed in the early G1 phase, as a molecular start of the cell cycle. Cyclin E is mainly involved in a later phase of the cell cycle and combines with $\mathrm{Cdk} 2$ to induce phosphorylation of the retinoblastoma protein $(\mathrm{Rb})$ protein. We thus believe that this process, especially in the early G1 phase, is important. Our results confirm earlier findings of aspirin-induced cell cycle arrest in many types of tumor cells (20-22). Our flow cytometry results showed that aspirin treatment significantly increased the proportion of early apoptotic cells. Meanwhile, the increased levels of caspase-cleaved cytokeratin 18 (cCK-18) and the decreased levels of clusterin and HSP 70 indicated apoptosis $(23,24)$. Clusterin is a stress-activated chaperone protein that plays an important role in various human malignancies, including $\mathrm{HCC}$, by promoting cell survival (25). It protects HCC cells from endoplasmic reticulum (ER) stress-induced apoptosis, partially by interacting with glucose-regulated protein 78 (GRP78) $(26,27)$. Many reports have indicated that clusterin could inhibit mitochondrial apoptosis by interacting with BAX (28) and activating the Akt and $\mathrm{NF}-\kappa \mathrm{B}$ pathways to promote cancer cell survival $(29,30)$. In a recent study, clusterin expression in nontumor liver tissue was found to be an independent adverse prognostic factor for post-operative HCC patients (31). HSP 70 , an evolutionarily conserved protein, is known to increase the survivability of cells under stress. Cells with HSP 70 knockdown are sensitive to apoptosis, while HSP 70 overexpression is shown to inhibit apoptosis (32). Previous research has indicated that aspirin induces apoptosis by altering the $\mathrm{Bax} / \mathrm{Bcl}-2$ ratio and activating caspase activity (33). Here, the aspirin-mediated decrease in the levels of clusterin and HSP 70 may partially induce apoptosis and therefore regulate cell proliferation in HCC cells.

miRNAs are a class of small (17-25 nucleotides), noncoding, endogenous, single-stranded RNA molecules that regulate target gene expression by interfering with their transcription or by inhibiting translation $(34,35)$. They are known to regulate the development and progression of various types of cancer $(36,37)$. In order to identify the miRNAs associated with the antitumor effects of aspirin, we used miRNA expression arrays following aspirin treatment of Huh-7 cells. Our results showed that in response to aspirin treatment, miR-7-5p levels were significantly decreased and miR-137 levels were significantly upregulated. Studies have reported a role of miR-137 in the inhibition of tumor growth and metastasis by targeting AKT serine/threonine kinase 2. A low miR-137 expression was significantly associated with lymph node metastasis, vein invasion, advanced clinical stage and poor prognosis in $\mathrm{HCC}$ (38-40). A related study showed that the overexpression of miR-137 downregulated the expression of $Z B T B$, a proto-oncogene reported to enhance HCC proliferation and multi-drug resistance (41). Based on these previous studies on miR-137, it was the first miRNA to be selected. Here, the results obtained following miR-137 mimic transfection indicated that miR-137 overexpression inhibited HCC cell proliferation, in accordance with previous research. In addition, EGFR is a predicted target gene of miR-137, and in 7 HCC cell lines, EGFR was overexpressed when compared to normal hepatocytes. We also detected that after transfection with miR-137 in Huh-7 cells, the levels of EGFR were significantly decreased, as well as the cell proliferation ability. Meanwhile, the undifferentiated cell lines (HLE, HLF), presented higher miR-137 levels when compared to hepatocytes and were less sensitive to the aspirin treatment. Furthermore, using p-RTK arrays, we demonstrated that aspirin reduced EGFR phosphorylation in Huh-7 cells. Overexpression of activated EGFR, an important signaling molecule associated with tumorigenesis, has been reported in $40-70 \%$ of human HCCs (42). EGFR can induce cyclin D1, an important protein in the cell cycle $(43,44)$, and may be pivotal in activating the sEGFR/Akt/NF- $\kappa \mathrm{B} /$ cyclin D1 (43) and JAK2/STAT3 signaling pathways $(45,46)$. Therefore, EGFR is an important link in regulating multiple signaling pathways and its inhibition by aspirin may affect regulatory proteins from multiple signaling pathways and induce apoptosis. Published research indicates that a close interaction between COX2 and EGFR signaling pathways, as well as COX2-derived prostanoids may be important in EGFR activation during the early stages of liver inflammation and carcinogenesis (47). Therefore, the miR-137/EGFR pathway could contribute to the aspirin-mediated antitumor effects noted in HCC cells. Additionally, miRNA-1225-5p has been reported as a tumor suppressor (48-50). These other upregulated miRNAs identified in this study have not yet been reported in HCC. However, these other upregulated miRNAs may be related to the antitumor effect of aspirin. In the near future, we aim to study the effects of these miRNAs on liver cancer. miR-7 was shown to modulate several signaling pathways and play a significant role in tumors such as HCC; miR-7 was found to inhibit p21-activated kinase 1 (Pak1) expression (51) and the PI3K/Akt pathway (52). MiR-7 was reported as being related to sorafenib resistance (SR) in HCC by modulating the expression of the TYRO3/phosphoinositide 3-kinase/protein kinase B signal transduction pathway (53). However, other research indicates the opposite role of miR-7 in the regulation of the complex networks of oncogenes (54).

A previous in vivo study used aspirin at a $60 \mathrm{mg} / \mathrm{kg}$ dose, which is equivalent to the daily human dosage of 240-330 mg (55). Our results revealed that aspirin markedly suppressed the growth of subcutaneous HCC tumors in athymic nude mice, suggesting that it may be effective in the development of a combination therapy with other anticancer drugs (56) for the treatment of HCC and possibly of other cancers.

Collectively, our results suggest that aspirin can inhibit human HCC cell proliferation by its multiple effects on the suppression of cell cycle-related molecules, induction of cell apoptosis and regulation of miRNA expression. In addition, we observed that aspirin may suppress cell proliferation partially through the miRNA-137/EGFR pathway. Although we observed a significant modulation in the expression of many miRNAs, the downstream targets of some of these molecules remain unknown and the roles of miRNAs in HCC remain to be elucidated. 


\section{Acknowledgements}

We thank Ms. Kayo Hirose, Ms. Keiko Fujikawa, Ms. Miwako Watanabe, Ms. Megumi Okamura, and Ms. Fuyuko Kokado for their assistance.

\section{Funding}

No funding was received.

\section{Availability of data and materials}

All data supporting the conclusions of the present study have been documented in this article.

\section{Authors' contributions}

TM, HK, AM and TTS conceived and designed the study. TTS, KF, JG, MN and HI performed the experiments. TTS wrote the paper. TTS, HI, SL, HY, TN, JT, KT, TT, TH, KO, KT and TM reviewed and edited the manuscript. All authors read and approved the manuscript and agree to be accountable for all aspects of the research in ensuring that the accuracy or integrity of any part of the work are appropriately investigated and resolved.

\section{Ethics approval and consent to participate}

All experimental protocols were approved by the Institutional Review Board of the Department of Laboratory Animal Science of Kagawa University (Kida, Japan).

\section{Patient consent for publication}

Not applicable.

\section{Competing interests}

The authors declare no competing interests.

\section{References}

1. Bray F, Ferlay J, Soerjomataram I, Siegel RL, Torre LA and Jemal A: Global cancer statistics 2018: GLOBOCAN estimates of incidence and mortality worldwide for 36 cancers in 185 countries. CA Cancer J Clin 68: 394-424, 2018.

2. Petrick JL, Kelly SP, Altekruse SF, McGlynn KA and Rosenberg PS Future of hepatocellular carcinoma incidence in the United States forecast through 2030. J Clin Oncol 34: 1787-1794, 2016.

3. Michel P, Boige V, Andre T, Aparicio T, Bachet JB, Dahan L, Guimbaud R, Lepage C, Manfredi S, Tougeron D, et al: Aspirin versus placebo in stage III or high-risk stage II colon cancer with PIK3CA mutation: A French randomised double-blind phase III trial (PRODIGE 50-ASPIK). Dig Liver Dis 50: 305-307, 2018.

4. Henry WS, Laszewski T, Tsang T, Beca F, Beck AH, McAllister SS and Toker A: Aspirin suppresses growth in PI3K-mutant breast cancer by activating AMPK and inhibiting mTORC1 signaling. Cancer Res 77: 790-801, 2017.

5. Yue W, Zheng X, Lin Y, Yang CS, Xu Q, Carpizo D, Huang H, DiPaola RS and Tan XL: Metformin combined with aspirin significantly inhibit pancreatic cancer cell growth in vitro and in vivo by suppressing anti-apoptotic proteins Mcl-1 and Bcl-2. Oncotarget 6: 21208-21224, 2015.

6. Gan H, Lin L, Hu N, Yang Y, Gao Y, Pei Y, Chen K and Sun B: Aspirin ameliorates lung cancer by targeting the miR-98/WNT1 axis. Thorac Cancer 10: 744-750, 2019.
7. Tao Y, Li Y, Liu X, Deng Q, Yu Y and Yang Z: Nonsteroidal anti-inflammatory drugs, especially aspirin, are linked to lower risk and better survival of hepatocellular carcinoma: A meta-analysis. Cancer Manag Res 10: 2695-2709, 2018.

8. Simon TG, Ma Y, Ludvigsson JF, Chong DQ, Giovannucci EL, Fuchs CS, Meyerhardt JA, Corey KE, Chung RT, Zhang X and Chan AT: Association between aspirin use and risk of hepatocellular carcinoma. JAMA Oncol 4: 1683-1690, 2018.

9. Zhang X, Feng H, Li Z, Guo J and Li M: Aspirin is involved in the cell cycle arrest, apoptosis, cell migration, and invasion of oral squamous cell carcinoma. Int J Mol Sci 19: E2029, 2018.

10. Liu YX, Feng JY, Sun MM, Liu BW, Yang G, Bu YN, Zhao M, Wang TJ, Zhang WY, Yuan HF and Zhang XD: Aspirin inhibits the proliferation of hepatoma cells through controlling GLUT1-mediated glucose metabolism. Acta Pharmacol Sin 40: 122-132, 2019.

11. Huang Z, Fang W, Liu W, Wang L, Liu B, Liu S and Liu S: Aspirin induces Beclin-1-dependent autophagy of human hepatocellular carcinoma cells. Eur J Pharmacol 823: 58-64, 2018.

12. Raza H, John A and Benedict S: Acetylsalicylic acid-induced oxidative stress, cell cycle arrest, apoptosis and mitochondrial dysfunction in human hepatoma HepG2 cells. Eur J Pharmacol 668: 15-24, 2011.

13. Pavlovic N, Rani B, Gerwins P and Heindryckx F: Platelets as key factors in hepatocellular carcinoma. Cancers (Basel) 11: e1022, 2019.

14. Malehmir M, Pfister D, Gallage S, Szydlowska M, Inverso D, Kotsiliti E, Leone V, Peiseler M, Surewaard BGJ, Rath D, et al: Platelet GPIb $\alpha$ is a mediator and potential interventional target for NASH and subsequent liver cancer. Nat Med 25: 641-655, 2019.

15. Livak KJ and Schmittgen TD: Analysis of relative gene expression data using real-time quantitative PCR and the 2(-Delta Delta C(T)) method. Methods 25: 402-408, 2001.

16. Dovizio M, Bruno A, Tacconelli S and Patrignani P: Mode of action of aspirin as a chemopreventive agent. Recent Results Cancer Res 191: 39-65, 2013.

17. Wang S, Yu Y, Ryan PM, Dang M, Clark C, Kontogiannis V, Rahmani J, Varkaneh HK, Salehisahlabadi A, Day AS and Zhang Y: Association of aspirin therapy with risk of hepatocellular carcinoma: A systematic review and dose-response analysis of cohort studies with 2.5 million participants. Pharmacol Res 151: $104585,2020$.

18. Pathi S, Jutooru I, Chadalapaka G, Nair V, Lee SO and Safe S: Aspirin inhibits colon cancer cell and tumor growth and downregulates specificity protein $(\mathrm{Sp})$ transcription factors. PLoS One 7: e48208, 2012.

19. Law BK, Waltner-Law ME, Entingh AJ, Chytil A, Aakre ME, Nørgaard P and Moses HL: Salicylate-induced growth arrest is associated with inhibition of p70s6k and down-regulation of c-myc, cyclin D1, cyclin A, and proliferating cell nuclear antigen. J Biol Chem 275: 38261-38267, 2000.

20. Gao L and Williams JL: Nitric oxide-donating aspirin induces G2/M phase cell cycle arrest in human cancer cells by regulating phase transition proteins. Int J Oncol 41: 325-330, 2012.

21. Dachineni R, Ai G, Kumar DR, Sadhu SS, Tummala H and Bhat GJ: Cyclin A2 and CDK2 as novel targets of aspirin and salicylic acid: A potential role in cancer prevention. Mol Cancer Res 14: 241-252, 2016.

22. Pozzoli G, Marei HE, Althani A, Boninsegna A, Casalbore P, Marlier LNJL, Lanzilli G, Zonfrillo M, Petrucci G, Rocca B, et al: Aspirin inhibits cancer stem cells properties and growth of glioblastoma multiforme through Rb1 pathway modulation. J Cell Physiol 234: 15459-15474, 2019.

23. Calderwood SK, Khaleque MA, Sawyer DB and Ciocca DR: Heat shock proteins in cancer: Chaperones of tumorigenesis. Trends Biochem Sci 31: 164-172, 2006.

24. Mustafi S, Sant DW, Liu ZJ and Wang G: Ascorbate induces apoptosis in melanoma cells by suppressing Clusterin expression. Sci Rep 7: 3671, 2017.

25. Zhang F, Kumano M, Beraldi E, Fazli L, Du C, Moore S, Sorensen P, Zoubeidi A and Gleave ME: Clusterin facilitates stress-induced lipidation of LC3 and autophagosome biogenesis to enhance cancer cell survival. Nat Commun 5: 5775, 2014.

26. Kang YK, Hong SW, Lee H and Kim WH: Overexpression of clusterin in human hepatocellular carcinoma. Hum Pathol 35: 1340-1346, 2004.

27. Wang C, Jiang K, Gao D, Kang X, Sun C, Zhang Q, Li Y, Sun L, Zhang S, Guo K and Liu Y: Clusterin protects hepatocellular carcinoma cells from endoplasmic reticulum stress induced apoptosis through GRP78. PLoS One 8: e55981, 2013. 
28. Xie D, Sham JS, Zeng WF, Che LH, Zhang M, Wu HX, Lin HL, Wen JM, Lau SH, Hu L and Guan XY: Oncogenic role of clusterin overexpression in multistage colorectal tumorigenesis and progression. World J Gastroenterol 11: 3285-3289, 2005.

29. Ammar $\mathrm{H}$ and Closset JL: Clusterin activates survival through the phosphatidylinositol 3-kinase/Akt pathway. J Biol Chem 283 12851-12861, 2008.

30. Zoubeidi A, Ettinger S, Beraldi E, Hadaschik B, Zardan A, Klomp LW, Nelson CC, Rennie PS and Gleave ME: Clusterin facilitates COMMD1 and I-kappaB degradation to enhance NF-kappaB activity in prostate cancer cells. Mol Cancer Res 8: 119-130, 2010.

31. Kuo PC, Chau IY, Li AF, Chau YP, Hsia CY and Chau GY: Clusterin expression in nontumor tissue in patients with resectable hepatocellular carcinoma related with postresectional survival. J Chin Med Assoc 82: 929-934, 2019.

32. Kumar S, Stokes J III, Singh UP, Scissum Gunn K, Acharya A, Manne U and Mishra M: Targeting Hsp70: A possible therapy for cancer. Cancer Lett 374: 156-166, 2016.

33. Hossain MA, Kim DH, Jang JY, Kang YJ, Yoon JH, Moon JO, Chung HY, Kim GY, Choi YH, Copple BL and Kim ND: Aspirin induces apoptosis in vitro and inhibits tumor growth of human hepatocellular carcinoma cells in a nude mouse xenograft model. Int J Oncol 40: 1298-1304, 2012.

34. Geng L, Chaudhuri A, Talmon G, Wisecarver JL, Are C, Brattain M and Wang J: MicroRNA-192 suppresses liver metastasis of colon cancer. Oncogene 33: 5332-5340, 2014.

35. Yuan Q, Cao G,Li J,Zhang Y and Yang W: MicroRNA-136 inhibits colon cancer cell proliferation and invasion through targeting liver receptor homolog-1/Wnt signaling. Gene 628: 48-55, 2017.

36. Yuan K, Xie K, Fox J, Zeng H, Gao H, Huang C and Wu M: Decreased levels of miR-224 and the passenger strand of miR-221 increase MBD2, suppressing maspin and promoting colorectal tumor growth and metastasis in mice. Gastroenterology 145 853-864.e9, 2013.

37. Morishita A and Masaki T: miRNA in hepatocellular carcinoma. Hepatol Res 45: 128-141, 2015.

38. Liu LL, Lu SX, Li M, Li LZ, Fu J, Hu W, Yang YZ, Luo RZ, Zhang CZ and Yun JP: FoxD3-regulated microRNA-137 suppresses tumour growth and metastasis in human hepatocellular carcinoma by targeting AKT2. Oncotarget 5: 5113-5124, 2014

39. Cui S, Sun Y, Liu Y, Liu C, Wang J, Hao G and Sun Q MicroRNA-137 has a suppressive role in liver cancer via targeting EZH2. Mol Med Rep 16: 9494-9502, 2017

40. Liang L, Li X, Zhang X, Lv Z, He G, Zhao W, Ren X, Li Y, Bian X, Liao W, et al: MicroRNA-137, an HMGA1 target, suppresses colorectal cancer cell invasion and metastasis in mice by directly targeting FMNL2. Gastroenterology 144: 624-635.e4, 2013.

41. Zhu M, Li M, Wang T, Linghu E and Wu B: MicroRNA-137 represses FBI-1 to inhibit proliferation and in vitro invasion and migration of hepatocellular carcinoma cells. Tumour Biol 37 13995-14008, 2016.

42. Buckley AF, Burgart LJ, Sahai V and Kakar S: Epidermal growth factor receptor expression and gene copy number in conventional hepatocellular carcinoma. Am J Clin Pathol 129: 245-251, 2008

43. Kato K, Gong J, Iwama H, Kitanaka A, Tani J, Miyoshi H, Nomura K, Mimura S, Kobayashi M, Aritomo Y, et al: The antidiabetic drug metformin inhibits gastric cancer cell proliferation in vitro and in vivo. Mol Cancer Ther 11: 549-560, 2012.
44. Liu W, Yin T, Ren J, Li L, Xiao Z, Chen X and Xie D: Activation of the EGFR/Akt/NF- $\mathrm{kB} /$ cyclinD1 survival signaling pathway in human cholesteatoma epithelium. Eur Arch Otorhinolaryngol 271: 265-273, 2014.

45. Li B, Ding CM, Li YX, Peng JC, Geng N and Qin WW: Over-regulation of microRNA-133b inhibits cell proliferation of cisplatin-induced non-small cell lung cancer cells through PI3K/Akt and JAK2/STAT3 signaling pathway by targeting EGFR. Oncol Rep 39: 1227-1234, 2018.

46. Han W and Lo HW: Landscape of EGFR signaling network in human cancers: Biology and therapeutic response in relation to receptor subcellular locations. Cancer Lett 318: 124-134, 2012.

47. Dajani OF, Meisdalen K, Guren TK, Aasrum M, Tveteraas IH, Lilleby P, Thoresen GH, Sandnes D and Christoffersen T: Prostaglandin E2 upregulates EGF-stimulated signaling in mitogenic pathways involving Akt and ERK in hepatocytes. J Cell Physiol 214: 371-380, 2008.

48. Li D, Chi G, Chen Z and Jin X: MicroRNA-1225-5p behaves as a tumor suppressor in human glioblastoma via targeting of IRS1. OncoTargets Ther 11: 6339-6350, 2018.

49. Sun P, Zhang D, Huang H, Yu Y, Yang Z, Niu Y and Liu J: MicroRNA-1225-5p acts as a tumor-suppressor in laryngeal cancer via targeting CDC14B. Biol Chem 400: 237-246, 2019.

50. Wang S, Chen X, Zhang Z and Wu Z: MicroRNA-1225-5p inhibits the development and progression of thyroid cancer via targeting sirtuin 3. Pharmazie 74: 423-427, 2019.

51. Reddy SD, Ohshiro K, Rayala SK and Kumar R: MicroRNA-7, a homeobox D10 target, inhibits p21-activated kinase 1 and regulates its functions. Cancer Res 68: 8195-8200, 2008

52. Fang Y, Xue JL, Shen Q, Chen J and Tian L: MicroRNA-7 inhibits tumor growth and metastasis by targeting the phosphoinositide 3-kinase/Akt pathway in hepatocellular carcinoma. Hepatology 55: 1852-1862, 2012.

53. Kabir TD, Ganda C, Brown RM, Beveridge DJ, Richardson KL, Chaturvedi V, Candy P, Epis M, Wintle L, Kalinowski F, et al: A microRNA-7/growth arrest specific 6/TYRO3 axis regulates the growth and invasiveness of sorafenib-resistant cells in human hepatocellular carcinoma. Hepatology 67: 216-231, 2018.

54. Cheng AM, Byrom MW, Shelton J and Ford LP: Antisense inhibition of human miRNAs and indications for an involvement of miRNA in cell growth and apoptosis. Nucleic Acids Res 33: 1290-1297, 2005

55. Mikami J, Kurokawa Y, Takahashi T, Miyazaki Y, Yamasaki M, Miyata H, Nakajima K, Takiguchi S, Mori M and Doki Y: Antitumor effect of antiplatelet agents in gastric cancer cells: An in vivo and in vitro study. Gastric Cancer 19: 817-826, 2016.

56. Li S, Dai W, Mo W, Li J, Feng J, Wu L, Liu T, Yu Q, Xu S, Wang W, et al: By inhibiting PFKFB3, aspirin overcomes sorafenib resistance in hepatocellular carcinoma. Int J Cancer 141: 2571-2584, 2017.

(i) 1 This work is licensed under a Creative Commons Attribution-NonCommercial-NoDerivatives 4.0 International (CC BY-NC-ND 4.0) License. 